\title{
Sovietski collection
}

Hvordan jeg er blevet indlemmet i den samling af mennesker, som modtager et katalog fra Sovietski collection i San Diego, Californien, er ikke klart. Jeg formoder, de har købt min adresse fra et af de bureauer, som handler med den slags. I god tid inden jul modtog jeg i alle tilfælde kataloget „Holiday Preview, 2001“, som indeholder tilbud på ting, som giver ,direct access to imperial and Cold War history“ (s. 2, min kursivering). Her er rustninger, ure, kikkerter, uniformsdele og flag, men også for eksempel legetøj, glas, samovarer og ikoner. Samlingen indeholder både kopier og originale genstande, som „Sasha (our man in Moscow...)“ har fundet frem af lagre og gemmer (s. 2).

Arjun Appadurai har diskuteret, hvorledes nutidige konsumptionsformer blandt andet er kendetegnede ved en form for nostalgi, der er løsrevet fra en forankring i en personlig eller social erindring (1996:75-9). En drivende kraft i det at samle er derfor i dag at opnå umiddelbar adgang til en fortid: at tilvejebringe mindet om et tab, som personen aldrig selv har lidt. Vi konsumerer således i en "ny økonomi”, hvor tids-rum er blevet kommer-cialiserede, gjort emotionelle og nostalgiske. Der er her ingen forskel på den kulturelle kvalitet af ting, som sælges i markedet for eksotiske repræsentationer for andre rum, som afrikanske masker eller tibetanske bedemøller, og den nostalgi for en historisk periode, som Sovietski collection promoverer: ,Today, the Cold War is but a chilly memory. These historic relics remind us of a time we would be well served never to forget" (s. 22, min kursivering). Men den amerikanske middelklasse, som Sovietski sælger til, erfarede og erfarer langt fra den kolde krig og de andre tids-rum, som markedsføres i kataloget. Chancen for, at konsumenterne glemmer den afstand, er uendelig meget større end muligheden for, at de personligt erindrer, hvordan det var at leve i den kolde krigs Øst.

Derfor bliver ,forbrugeroplysning“ af afgørende betydning: Hvad er det, vi skal huske, vi har mistet, når vi berøres af denne genstand? Tingene i kataloget forsynes med en historie, som naturligvis skal overbevise konsumenten om at købe, men som også oplyser om varens nostalgiske kvaliteter. I en del tilfælde er yderligere informationer også inkluderet i købet: „Story card included“ (Soviet military patches, s. 25). Gennem historierne føres "kundskab" om andre tids-rum desuden videre til kommende generationer - hvis forventede fremtidige nostalgi i øvrigt allerede nu kan markedsføres: „Adds a touch of nostalgia to your table... destined to be a heirloom“ (Your babushka's flatware, s. 42).

Min personlige favorit i samlingen af små historier, jeg og andre modtagere af kataloget ikke kan erindre os, er:

Authentic Swedish M 1914 bayonet

During the Great War (WWI), brave Swedish soldiers charged the enemy with only one round in the chamber and a bayonet like this affixed to the end of their M94-14 carbine. Here's a blade you can count on - still in excellent condition nearly a century later! Crown and anchor insignia and the initials EJAB (Eskiltuna Jern Manufacturing, Inc) engraved on the base of the $12^{1 / 2^{\prime \prime}}$ blade (s. 14).

For \$59 får du en troværdig repræsentation for svensk heroisme og europæisk krigshistorie, som du kan vise frem og fortælle om. Det spiller ingen rolle, at du ikke var med ved Stormen på Hallandsåsen eller Slaget ved Tomelilla. Gennem andre medier, historie- 
bøger, film og så videre, er imaginære landskaber for denne del af din samling allerede trukket op. Du behøver blot at berøre din tilhører med det historiske relikvie, for at hun/ han skal få umiddelbar adgang til den samme nostalgiske oplevelse, du selv allerede har erfaret, af at have mistet noget du aldrig havde: erindringen om Verdenskrig, heroisme og social kontekst - de andre tapre svenske soldater.

Det er vel her, grænsen for en samling erhvervet i dagens marked går. Hvis ikke konsumenten oplever nostalgi frigjort fra egen erindring, men forankret i det konkrete objekt som et relikvie, så er en samling enten didaktisk, som museerne ofte var tænkt, en investering, eller blot en simpel ophobning af ting; således som kataloget fra Sovietski collection naturligvis også kan læses af den, som ikke er samler.

Anders Linde-Laursen, antropolog

\section{Henvisninger}

2001 Sovietski collection. Unique Russian and Eastern European Gear, Gifts and Collectibles. Holiday Preview (se også: www.sovietski.com).

Appadurai, Arjun

1999 Modernity at Large. Cultural Dimensions of Globalization. Minneapolis: University of 